than that which your suggestion employs. I have made Cantani's bacterium termo the basis. In a letter which I received from him occur these words: "Le B. termo, qui m'a servi si bien contre la phthisie, est une espèce particulière du genus Termo, qui végéte bien à $39-40 \mathrm{C}^{\circ}$. On doit si le procurer dans un laboratoire bactériologique et le cultiver toujours pur." Here are four particulurs: (1) a particular species; (2) a particular laboratory; (3) a particular temperature; (4) a particular cultivation. To avoid the confusion of species which Pawlowsky condemns, minute attention to these particulars is requisite; and no one who has not diligently tried can estimate the trouble of sterilising the suitable fluid and thus sowing that bacterium, and the number of times it is necessary after every precaution to go over and over the same ground to secure the culture of one species, and one species alone; and yet this point secured is only the beginning. To find the way out of the morass, too much attention cannot be paid to your direction-viz, "to afford to the organism support sufficient to cope with the bacterial hordes-to strengthen the powers of vital resistance." To secure this end, every means within my reach has been resorted tonutritious food, tonic and strengthening medicines, daily inunctions of cod-liver oil, thorough ventilation of apartments, disinfectants, change of air, long continuance in the onen air, and, latterly, the addition of the sulphuretted hydrogen rectal injections of Bergeon.

Now for results. Were $I$ to send you a table or chart describing cases from the commencement to the conclusion, it would claim too much of your space. Suffice it to say, I can point to patients, not only in Liverpool, but in London and various other places - patients, the first account of whose symptoms would have left no ray of hope under the old methods of treatment; patients, now convalescent, who were pronounced to be in advanced phthisis by other physicians before bacterium termo and vital restoratives combined yielded the wished-for consummation. The desire that similar success may attend the efforts of others induces me to write thus. Truly the morass is a deep one. It is daily engulphing victims; but there is a way out, and some have securely walked it. To induce others to try the path you advucate is $m y$ apology for thus intruding on your valuable space. $\quad[\mathrm{am}$, Sirs, yours faithfully,

Liverpool, Aug. 23rd, 1887. W. H. LAMBART, M.D., F.R.C.S.

P.S.-It will give me pleasure to supply, free of charge, a pure cultivation to any medical brother who is anxious to give this treatment a fair trial.

\section{THE PASTEUR COMMTTTEE.}

\section{To the Editors of THE LANCET.}

SIRS,--It may appear to be presumptuous on the part of so humble a member of the profession as $I$ am to record my objection to the report of the committee appointed to inquire into the value of Pasteur's method. Nevertheless, I feel sure many will agree with me that the report is not satisfactory so far as the main question at issue is concerned. The committee appear to have experienced no difficulty in obtaining facilities for experimentally testing the prophylactic value of Pasteur's method, but what I think required to be shown in the same manner was whether it possessed antidotal powers. No attempt whatever seems to have been made to submit this matter to experimental test. It is true that the committee offer an opinion, but it is founded upon a critical analysis of Pasteur's cases. Even supposing the committee had met most of the principal objections to these cases, which, with all due deference to those eminent gentlemen, I may venture to say appears not to have been the case, their decision, however much entitled to respect, would, after all, only be a matter of opinion. I humbly submit that what is required to be tested by experiment is this: (a) Does inoculation with Pasteur's material prevent the occurrence of rabies after infection has taken place? (b) If so, what is the shortest period after infection that it does so?

Surely, in the absence of any experimental researches, the success of the method as a remedial measure is as far from demonstration as ever. I am, of course, assuming that the abstract contained in your issue of July 2nd, 1887, from which my information is obtained, accurately describes the report of the committee. More than twenty years' practical experience in investigations of a somewhat similar nature must be my respectful apology for this communication, July 24th, 1837 I am, Sirs, yours truly, VINCENT RTCHARDS.

\section{THE ORGANISMS OF MALARIA IN THE EAST.} To the Editors of THE LANCET.

SIRS,-It may interest some of your readers to hear that the micro-organisms of the blood supposed to be characteristic of the malarial infection have been found almost daily, for some time past, in two patients at present lodged in the clinical medical wards at the Jamsetjee Jejeebhoy Hospital, Bombay. They have been seen not only by mystlf in charge, but also by Professors Manser, Macdonald, and Burke. Stained preparations are preserved, and on careful comparison with the original descriptions of Professors Laveran, now of Paris, and Osler of Philadelphia, there seems to be no doubt of the identity of the "hæmatozon of ague," sometimes at least, found in this part of India, with the organisms now known to prevail in parts of Europe, Africa, and America. Several interesting questions are raised by these recent observations, which can be fully answered only after a prolonged research. Hitherto, after a brief inquiry, it has not appeared to me that the pigmented monads, of either spheroidal or crescentic shape, are usually or distinctly present in the blood of patients affected with the common so-called "malarious remittent" fever of Bombay. Nor have they been detected in four pronounced examples of "malarial cachexia." According to my experience, genuine "ague" here is almost invariably an importation; and as regards the two positive instances above named, it happens that the quotidian and quartan types they represent were acquired outside the limits of the western Presidency. About two years since a futal case of "pernicious" malarial fever came under my care from the N.W. frontier, and in it the blood was loaded with pigment in a striking degree. (Vide Trans. Med. and Phys. Soc, Bombay, No. 8, new series, 1886. .

I am, Sirs, your obedient servant,

Grant Med. Coll., Bombay, July 28th, 1887.

H. V. Carter.

\section{THE STATE OF THE THAMES.}

\section{To the Eaitors of THE LANCET.}

SIRS,-Perhaps you may not disdain to receive the congratulations of a simple engineer upon the correct views expressed on several occasions on the above subject by the leading medical journal, and your clear short article in your issue of to-day, the $13 \mathrm{ch}$ inst., presents a striking contrast to a long and lame apology for chemical failure published by the Engineer newspaper on the 5th instant, This paper has devoted many leading articles during the last two years to the advocacy of an ingenious theory set up by Mr. Dibdin, chemist to the Metropolitan Boaro of Works, and has striven by faint praise of the permanent remedy recommended by Lord Bramwell's Royal Commission to exalt the supposed economy of experimenting with permanganate of soda. These articles contained internal evidence of acquaintance with unreported proceedings of the Board in pursuance of their chemist's advice, which led me to refer to them as "semiofficial" in one or two letters published without disclaimer by the Engineer; but the article of the 5th inst. has "let the cat out of the bag," and shown that its editor sympathise. with the Board so long only as its majority was content to follow the lead of their chemist, and proceeds to taunt the Board with "drifting" towards Canvey Island.

Now, I would ask your readers if it is right that a problem of such public importance as that now before the Metropolitan Board should be treated by anyone in such a spirit as seems to be indicated by the word "drifting," and still more by the following further quotation from the Engineer of the 5th inst.:- "Without really intending it, the Board is now playing into the hands of Mr. Bailey-Denton and his colleague."

I am, Sirs, your obedient eervant,

Wrexham, Aug. 13th, 1887. 